\title{
Effects of resistance training and turmeric supplementation on reactive species marker stress in diabetic rats
}

\author{
Ailton Santos Sena Júnior ${ }^{1}$, Felipe José Aidar ${ }^{1,2}$, Jymmys Lopes Dos Santos ${ }^{1,3}$, Charles Dos Santos Estevam², \\ Jessica Denielle Matos dos Santos ${ }^{1}$, Ana Mara de Oliveira e Silva ${ }^{4}$, Fábio Bessa Lima ${ }^{5}$, Silvan Silva De Araújo ${ }^{1}$ and \\ Anderson Carlos Marçal ${ }^{6^{*}}$ (D)
}

\begin{abstract}
Background: Type 1 diabetes mellitus (T1DM) is a metabolic disease characterized by hyperglycemia and excessive generation of reactive oxygen species caused by autoimmune destruction of beta-cells in the pancreas. Among the antioxidant compounds, Curcuma longa (CL) has potential antioxidant effects and may improve hyperglycemia in uncontrolled T1DM/TD1, as well as prevent its complications (higher costs for the maintenance of health per patient, functional disability, cardiovascular disease, and metabolic damage). In addition to the use of compounds to attenuate the effects triggered by diabetes, physical exercise is also essential for glycemic control and the maintenance of skeletal muscles. Our objective is to evaluate the effects of $\mathrm{CL}$ supplementation associated with moderate- to high-intensity resistance training on the parameters of body weight recovery, glycemic control, reactive species markers, and tissue damage in rats with T1DM/TD1.
\end{abstract}

Methods: Forty male 3-month-old Wistar rats (200-250 g) with alloxan-induced T1DM were divided into 4 groups $(n=7-10)$ : sedentary diabetics (DC); diabetic rats that underwent a 4-week resistance training protocol (TD); CLsupplemented diabetic rats (200 mg/kg body weight, 3x a week) (SD); and supplemented diabetic rats under the same conditions as above and submitted to training (TSD). Body weight, blood glucose, and the following biochemical markers were analyzed: lipid profile, aspartate aminotransferase (AST), alanine aminotransferase (ALT), uric acid, creatine kinase (CK), lactate dehydrogenase ( $(D D H)$, and thiobarbituric acid reactive substances (TBARS).

Results: Compared to the DC group, the TD group showed body weight gain ( $\uparrow 7.99 \%, p=0.0153)$ and attenuated glycemia $(\downarrow 23.14 \%, p=0.0008)$ and total cholesterol $(\downarrow 31.72 \%, p \leq 0.0041)$ associated with diminished reactive species markers in pancreatic $(\downarrow 45.53 \%, p<0.0001)$ and cardiac tissues $(\downarrow 51.85 \%, p<0.0001)$. In addition, compared to DC, TSD promoted body weight recovery $(\uparrow 15.44 \%, p \leq 0.0001)$; attenuated glycemia $(\downarrow 42.40 \%, p \leq 0.0001)$, triglycerides $(\downarrow 39.96 \%, p \leq 0.001)$, and total cholesterol $(\downarrow 28.61 \%, p \leq 0.05)$; and attenuated the reactive species markers in the serum $(\downarrow 26.92 \%, p \leq 0.01)$, pancreas $(\downarrow 46.22 \%, p \leq 0.0001)$, cardiac $(\downarrow 55.33 \%, p \leq 0.001)$, and skeletal muscle $(\downarrow 42.27 \%, p \leq 0.001)$ tissues caused by T1DM.

(Continued on next page)

\footnotetext{
* Correspondence: acmarcal@yahoo.com.br

${ }^{6}$ Department of Morphology, Universidade Federal de Sergipe, São Cristóvão, Sergipe, Brazil

Full list of author information is available at the end of the article
}

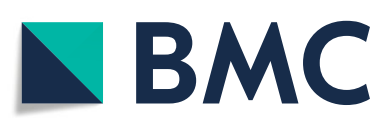

(c) The Author(s). 2020 Open Access This article is licensed under a Creative Commons Attribution 4.0 International License, which permits use, sharing, adaptation, distribution and reproduction in any medium or format, as long as you give appropriate credit to the original author(s) and the source, provide a link to the Creative Commons licence, and indicate if changes were made. The images or other third party material in this article are included in the article's Creative Commons licence, unless indicated otherwise in a credit line to the material. If material is not included in the article's Creative Commons licence and your intended use is not permitted by statutory regulation or exceeds the permitted use, you will need to obtain permission directly from the copyright holder. To view a copy of this licence, visit http://creativecommons.org/licenses/by/4.0/ The Creative Commons Public Domain Dedication waiver (http://creativecommons.org/publicdomain/zero/1.0/) applies to the data made available in this article, unless otherwise stated in a credit line to the data. 
(Continued from previous page)

Conclusion: Resistance training associated (and/or not) with the use of Curcuma longa attenuated weight loss, the hypoglycemic and hypolipidemic effects, reactive species markers, and T1DM-induced tissue injury.

Keywords: Turmeric, Resistance training, Diabetes mellitus

\section{Background}

Diabetes mellitus $(\mathrm{DM})$ is one of the most serious diseases affecting the population worldwide, and it is estimated that the world's diabetic population will be 578 million in 2030 and 700 million in 2045 [1]. This epidemic has a higher rate of incidence in both developed and developing countries [2-4]. International guidelines such as the American Diabetes Association and the World Health Organization classify DM into four categories: Type 1 DM (T1DM), Type 2 DM (T2DM), Other Types, and Gestational Diabetes. Type $2 \mathrm{DM}$ is the most prevalent form of the disease, accounting for approximately $90 \%$ of the cases in the world's population [5-7].

Patients with T1DM typically have residual or no insulin production due to loss of functioning of pancreatic beta cells $[2,8,9]$. When not promptly treated with insulin, these patients develop marked hyperglycemia and ketosis with consequent hyperketonemia, proteolysis and lipolysis. Conversely, T2DM is intimately correlated with long-term insulin resistance and compensated hyperinsulinemia, which progresses to T2DM when the insulin response to glucose demands becomes insufficient, leading to insulinopenia with consequent hyperglycemia. At the diagnosis of T2DM, approximately $50 \%$ of beta cells are not functioning, in a state of mix of impairments between insulin production and action. In contrast to T1DM, patients affected by T2DM are typically asymptomatic and only develop manifestations either when insulin production becomes vestigial and a ketogenic state is instated or by one of the multiple diabetic complications $[2,8,9]$.

Despite the different types of diabetes, overall and individual medical costs and loss of income have been reported to be higher in patients with T1DM compared to T2DM $[10,11]$. T1DM is considered to be an inflammatory and autoimmune disorder that results from the infiltration of autoreactive $\mathrm{T}$ lymphocytes and the consequent generation of proinflammatory cytokines and the appearance of excessive reactive oxygen species (ROS). As a consequence, increased pancreatic $\beta$ cell death results in hyperglycemia, which is dependent on exogenous insulin administration, concomitantly with evident glucagon secretion imbalance [12-14].

Pharmacological treatment of diabetes includes insulin and hypoglycemic and anti-hyperglycemic drugs, which will depend on the stage and type of DM. Lifestyle changes are also recommended as nonpharmacological approaches/modalities, among which the most widespread and proven ones are regular exercise and healthy eating [2, 3, 15-17]. In particular, exercise is able to promote beneficial adjustments in aerobic capacity and lipid and glycemic control, as it controls insulin and glucose homeostasis, promotes increased fatty acid oxidation in the muscles, reduces blood glucose concentration, attenuates systemic inflammation and improves immune cell functions $[18,19]$.

Some authors suggest that resistance training may be recommended as an important therapy in diabetes because it increases skeletal muscle glucose uptake. This is partly due to the action of exercise that promotes increased glucose transporter 4 (GLUT-4) translocation and improved insulin-independent glucose uptake pathway functionality [20]. In addition to this evidence, some authors suggest that physical exercise also improves antioxidant defenses and mitochondrial activity due to the reduction of reactive species [19, 21-23].

On the other hand, the use of herbal medicines to promote glycemic and metabolic homeostasis in pathological conditions such as DM is becoming increasingly popular in the world's population [24]. In this context, supplementation with turmeric (Curcuma longa L.), in different ways, appears to act beneficially on glycemic control; these effects are partly due to an attenuation of insulin resistance and frequently encountered comorbidities in patients with diabetes $[25,26]$. Some authors suggest that these effects of turmeric are partly due to the high concentrations of curcumin that have antioxidant action [27-29]. Studies have shown that curcumin also has protective effects, such as increased antioxidant activity of enzymes and mitigation of mitochondrial dysfunction and liver damage [30, 31].

Despite this evidence, some authors showed that the use of high doses of natural supplements at supraphysiological concentrations may result in possible overall risks to health and/or no effects on the whole body, since the safety profile has not been established for the aboverecommended dosages [32]. For this reason, it is imperative that personalized antioxidant supplementation may improve performance exercise. This is due, at least in part, to a fine synchronic adjustment of the redox system, as well as other molecular mechanisms that are recruited during exercise adaptation [33]. 
The present study aimed to evaluate the effects of medium- to high-intensity resistance training associated (or not) with the supplementation of Curcuma longa on body weight recovery, blood glucose, lipid profile, reactive species, and muscle damage in Wistar T1DM rats.

\section{Methods}

\section{Animals}

Forty male 3-month-old Wistar rats weighing approximately 250-300 g from the Sector Vivarium of the Intracellular Signaling Research Center of the Federal University of Sergipe were used in this study. They were randomly housed in appropriate conditions $-22 \pm 3{ }^{\circ} \mathrm{C}$, 12-h light/dark cycle (300 lx of light), and free access to rodent-specific feed (Labina ${ }^{\circ}$ ) and water ad libitum. The methodology used in the present study were approved by the Ethics Committee on Animal Research of the Federal University of Sergipe (CEPA Protocol 72/18).

\section{Induction of diabetes mellitus}

Experimental DM was induced as described by Santos et al. [34], briefly an solution of $2 \%$ aqueous alloxan solution (single dose of $150 \mathrm{mg} / \mathrm{kg}$ ) (alloxan monohydrate A7413 - Sigma, St. Louis, USA) was injected intraperitoneally into 40 animals. One week after the administration the animals underwent a 24-h fast to enhance the drug's sensitivity and diabetogenic action with water supply ad libitum. The alloxan administration was conducted and, $30 \mathrm{~min}$ after, feed was offered to all groups to prevent hypoglycemia. Blood was collected by caudal puncture for the blood glucose by means of an AccuChek Go glucometer (Roche Diagnostics GmbH, D68298, Mannheim, Germany) test $72 \mathrm{~h}$ after of induction. Only animals with fasting blood glucose of $200 \mathrm{mg} / \mathrm{dL}$ or higher were included in the study, starting in the treatment and resistance training protocol (RTP) protocol.

\section{Resistance training protocol}

RTP was performed by means of a flexion-extension (which involves the soleus, extensor digitorum longus, and gastrocnemius muscular groups) using a squat machine. The animals wore a jacket that connected them to a articulated $35-\mathrm{cm}$-long wooden bar where the loads were allocated. During the routine, the rats were sited on their back legs, according to the method by Tamaki et al. [35] and adapted by Santos et al. [34].

All animals used the equipment for one week in order to get used to it and also received electrostimulation. Afterwards, the DT and TSD animals underwent the training protocol of $3 \times 10$ repetitions, with intervals of 60 s between the sets, at an intensity of $70 \%$ of the load that was established by the one-repetition maximum (1RM) test [35]. The RT was performed three times a week for four weeks every other day [34, 35]. The load used in the training routine was adjusted every two weeks following a new 1RM test. The DC and SD animals underwent the same methodology but with no load and $0 \%$ intensity (Table 1 ). The electrical stimulation (20 V/0.3 s in duration, 3-s interval) was applied to using electrodes (ValuTrode, Model CF3200, Axelgaard, Fallbrook, CA, USA) fixed to their tail by an electrostimulator (BIOSET, Physiotonus Four, Model 3050, Rio Claro, SP, Brazil). The load used was low and did not induce changes in the stress predictors [36].

\section{Experimental groups}

The body weight measurement and blood glucose were checked once each week. Curcuma longa supplementation and the RTP protocol were performed three times per week. The animals were divided into four groups ( $n=7-10$ for each group): 1) diabetic control group (DC): diabetic and sedentary animals treated with vehicle (distilled water, oral) + electrostimulation with no load on the apparatus; 2) trained diabetics (TD): diabetic animals treated with vehicle and submitted to RTP; 3) supplemented diabetics (SD): diabetic animals treated with Curcuma longa L. extract $(200 \mathrm{mg} / \mathrm{kg}$, orally) + electrostimulation with no load on the apparatus; 4) trained supplemented diabetics (TSD): diabetic animals treated with Curcuma longa L. extract $(200 \mathrm{mg} / \mathrm{kg}$ orally) and submitted to RTP.

\section{Supplementation}

Supplementation consisted of administering Curcuma longa extract from the manufacturer Florien, São Paulo, Brazil, with Internal Lot \#: 18A20-B018-028830 and Manufacturer Lot \#: CJH-A-706694. The extract was administered at a dose of $200 \mathrm{mg} / \mathrm{kg}$ three times per week, always at the same time after the RTP protocol by oral

Table 1 Resistance training protocol

\begin{tabular}{llllll}
\hline Week & Intensity (\%) & Days in the week ${ }^{\text {a }}$ & Number of series & Repetitions $(\mathrm{n})$ & Interval (seconds) \\
\hline 1st & 70 & 3 & 3 & 10 & 60 \\
2nd & 70 & 3 & 3 & 10 & 60 \\
3rd & 70 & 3 & 3 & 10 & 60 \\
4th & 70 & 3 & 3 & 10 & 60 \\
\hline
\end{tabular}

Model proposed by Tamaki et al. [35] and ${ }^{\text {a }}$ adapted by Santos et al. [34] 
gavage using a rodent-specific stainless-steel cannula with a rounded end not to cause any injury.

\section{Sample collection}

All the animals were euthanized at the end of the study (30 days) with a solution of ketamine $(100 \mathrm{mg} / \mathrm{kg})$ and xylazine $(10 \mathrm{mg} / \mathrm{kg})$ administrated intraperitoneally, and then, their blood and organs (pancreas, heart, liver, and gastrocnemius muscle) were collected, weighed, and stored for later analysis.

\section{Determination of serum biochemical markers}

Blood was centrifuged at $800 \times g$ for $15 \mathrm{~min}$ at $4{ }^{\circ} \mathrm{C}$, and the serum was stored at $-80^{\circ} \mathrm{C}$. The serum was used to measure the concentrations of triglycerides, total cholesterol and HDL cholesterol (HDL), alanine aminotransferase (ALT), aspartate aminotransferase (AST), creatine kinase (CK), lactate dehydrogenase (LDH), and uric acid according to the manufacturer's procedures (Labtest ${ }^{\oplus}$, Lagoa Santa, Minas Gerais, Brazil). The reactive species markers were also evaluated as follows: lipoperoxidation was evaluated by thiobarbituric acid reactive substances (TBARS) following the method proposed by Lapenna et al. [37].

\section{Determination of tissue reactive species markers (TBARS)}

The organs were washed three times in a potassium chloride solution $(1.15 \% \mathrm{KCl})$ and homogenized $(1: 5 \mathrm{p} /$ v) with $\mathrm{KCl}$ solution, phenylmethylsulfonyl fluoride (PMSF 100 m.mol-1), and Triton solution (10\%). Immediately thereafter, the homogenates were centrifuged at $3000 \times g$ for $10 \mathrm{~min}$ at $4{ }^{\circ} \mathrm{C}$, and the supernatant was stored at $-80^{\circ} \mathrm{C}$ for the analysis of reactive species markers (TBARS). The results were expressed per gram of tissue.

\section{Statistical analysis}

All the statistical analysis was performed in the software Graph Pad Prism version 5.0 and the outcome is presented as the mean \pm standard deviation $(\mathrm{X} \pm \mathrm{SD})$ as a result of a triplicate analysis (to TBARS samples). Firstly, the data was evaluated about its normality, using the Shapiro Wilk test, afterwards they were statistically evaluated among groups by one-way analysis of variance (ANOVA one way) and post hoc Bonferroni test. Two of the groups were statistically evaluated by using the $t$-test. The statistically significant difference between the samples adopted was $p<0.05$.

\section{Results}

The diabetic animals of all groups presented polyuria, polydipsia, and polyphagia (data not shown) in the $72 \mathrm{~h}$ after alloxan induction, and the symptoms remained until the last day of the experiment.
Figure 1a represents the results regarding the body weight of the groups at the end of the experimental period. The animals belonging to the TD, SD, and TSD groups presented a body weight increase of $7.99 \%$ (TD = $246.01 \pm 17.5 \mathrm{~g}, p=0.0153), 10.97 \%(\mathrm{SD}=252.9 \pm 14.01 \mathrm{~g}$, $p \leq 0.01)$, and $15.45 \%(\mathrm{TSD}=263.1 \pm 15.73 \mathrm{~g}, p \leq 0.001)$, respectively, when compared to the diabetic group without any intervention ( $\mathrm{DC}=227.9 \pm 6.556 \mathrm{~g})$. When comparing the TD, SD, and TSD groups, there were no significant differences among them.

Figure $1 \mathrm{~b}$ represents the plasma glucose of the different experimental groups. The TD group at the end of the experiment showed a reduction of $23.14 \%$ (368.0 \pm $53.22 \mathrm{mg} / \mathrm{dL}, p=0.0008)$ compared to the DC group $(478.8 \pm 50.06 \mathrm{mg} / \mathrm{dL})$. This reduction was similar in the SD $(355.0 \pm 90.93 \mathrm{mg} / \mathrm{dL})$ and TSD $(275.8 \pm 111.4 \mathrm{mg} /$ dL) groups, which were approximately $25.86 \%(p \leq 0.05)$ and $42.40 \%(p \leq 0.001)$ lower, respectively, when compared with the DC group. When comparing the TD, SD and TSD groups, there were no significant differences among them.

The concentrations of aspartate aminotransferase (AST) (Fig. 1c) in the DC $(164.4 \pm 40.85 \mathrm{UI} / \mathrm{L}), \mathrm{TD}$ $(129.7 \pm 61.86 \mathrm{UI} / \mathrm{L})$, and SD $(155.1 \pm 51,35 \mathrm{UI} / \mathrm{L})$ groups were similar. The results show that there was a $49.69 \%$ $(p \leq 0.05)$ and $46.67 \%(p=0.042)$ reduction in the TSD group $(82.71 \pm 18.03 \mathrm{UI} / \mathrm{L})$ when compared to the DC and SD groups, respectively. When comparing the TD and TSD groups, there was no significant difference between them.

In Fig. 1d, the plasma alanine aminotransferase (ALT) content was reduced by $40.14 \%(p=0.085)$ in the TD $(146.1 \pm 50.46 \mathrm{UI} / \mathrm{L}), \quad 38.30 \%(\mathrm{p} \leq 0.05)$ in the SD $(150.6 \pm 41.63 \mathrm{UI} / \mathrm{L})$, and $45.60 \%(p \leq 0.001)$ in the TSD $(132.9 \pm 40.54 \mathrm{UI} / \mathrm{L})$ groups compared with the DC group $(244.1 \pm 65.42 \mathrm{UI} / \mathrm{L}(p<0.05)$. When comparing the TD, SD, and TSD groups, there were no significant differences among them.

Regarding HDL cholesterol (Fig. 2a), there was a $60.30 \%(p=0.0001)$ increase in the TD group (42.88 \pm $7.28 \mathrm{mg} / \mathrm{dL})$ and $80.37 \%(p \leq 0.001)$ in the TSD group compared to the DC group $(26.75 \pm 4.89 \mathrm{mg} / \mathrm{dL})$. There was also an increase of $60.38 \%(p \leq 0.0001)$ in the TSD group $(48.25 \pm 5.50 \mathrm{mg} / \mathrm{dL})$ compared to the SD $(30.0 \pm$ $7.87 \mathrm{mg} / \mathrm{dL}$ ) group. When the values of HDL cholesterol in the SD group were compared to the TD group, there was an increase of $30.04 \%$ ( $p \leq 0.001)$.

For the concentrations of uric acid (Fig. 2b), there was a reduction of $19.54 \%(p=0.0027)$ in the TD group $(4.99 \pm 0.584 \mathrm{mg} / \mathrm{dL}), 18.34 \%(p \leq 0.01)$ in the SD group $(5.063 \pm 0.5263 \mathrm{mg} / \mathrm{dL})$, and $38.31 \%(p \leq 0.001)$ in the TSD group $(3.825 \pm 0.6902 \mathrm{mg} / \mathrm{dL})$ compared to the DC $(6.20 \pm 0.740 \mathrm{mg} / \mathrm{dL})$ group. The results show that there was a $24.45 \%(p=0.0012)$ reduction in the TSD group 
A

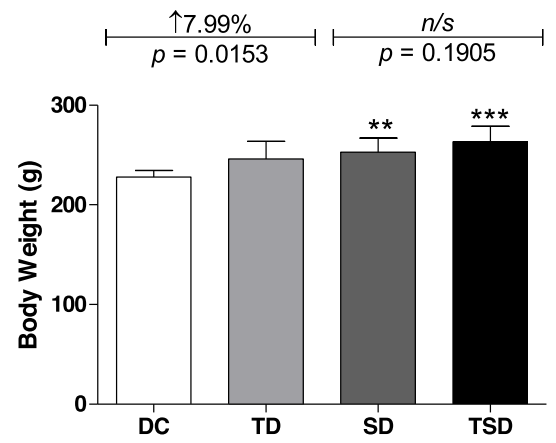

C

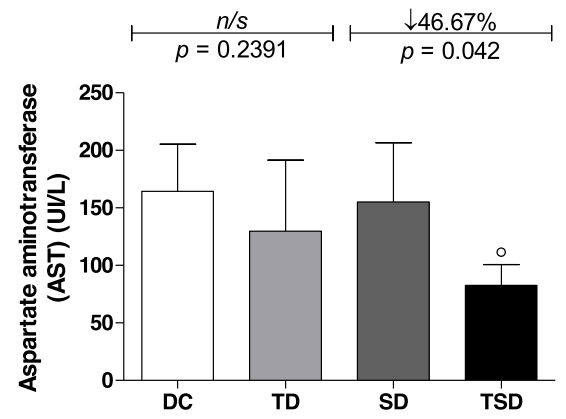

B
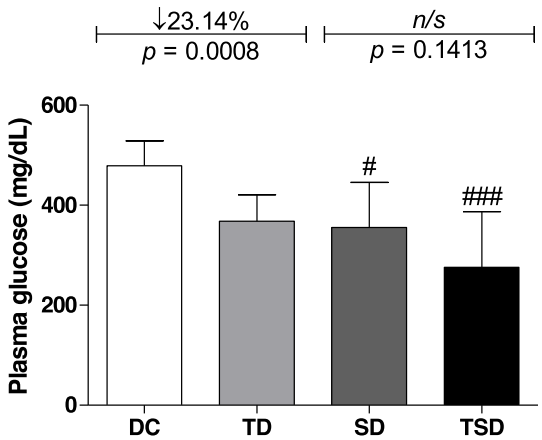

D

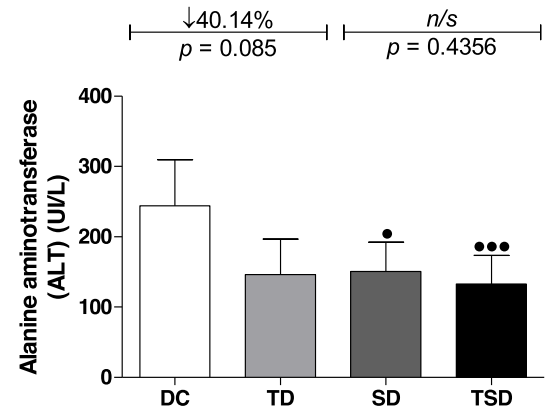

Fig. 1 Analysis of body weight, fasting plasma glucose, aspartate aminotransferase, and alanine aminotransferase of the diabetic animals group (DC) (white bar); trained diabetics (TD) group submitted to resistance training for four weeks (light gray bar); supplemented diabetics (SD) group receiving $200 \mathrm{mg} / \mathrm{kg}$ body three times per week for four weeks (dark gray bar); and trained and supplemented diabetics (TSD) group submitted to Curcuma longa supplementation and the resistance training program simultaneously (black bar). Body weight (a), fasting plasma glucose (b), aspartate aminotransferase (AST) (c) and alanine aminotransferase (ALT) (d). Data represent the mean \pm standard deviation of the mean. One-way analysis of variance (ANOVA one way) and post hoc de Bonferroni tests were used. Letters on the bars represent the significant difference by one-way ANOVA followed by Bonferroni's test among the groups as follows: body weight ( ${ }^{* *} p \leq 0.01$ for DC vs. SD; ${ }^{* * *} p \leq 0.001$ for DC vs. TSD), glucose ( $p \leq 0.05$ for DC vs. SD; \#\# $p \leq 0.001$ for DC vs. TSD), AST ( $p \leq 0.05$ for DC vs. TSD), and ALT $(\bullet p \leq 0.05$ for DC vs. SD; $\cdots p \leq 0.001$ for DC vs. TSD). For the DC vs. TD and SD vs. TSD groups, Student's t-test was used. ns = no significant difference. $n=7-8$ in all experimental groups

compared to the SD group. When the uric acid levels of the TSD group were compared to those of the TD group, there was a reduction of $23.34 \%(p \leq 0.01)$.

Figure 2c shows the results for the triglyceride concentration where no significant difference occurred between the DC $(127.9 \pm 22.30 \mathrm{mg} / \mathrm{dL})$ and TD $(115.4 \pm 26.45 \mathrm{mg} /$ $\mathrm{dL})$ groups, nor in the $\mathrm{SD}(95.43 \pm 20.33 \mathrm{mg} / \mathrm{dL})$ group. However, the results show that there was a reduction of $39.96 \%(p \leq 0.01)$ and $23.14 \%(p \leq 0.05)$ in the TSD $(77.14 \pm 15.03 \mathrm{mg} / \mathrm{dL})$ group when compared to the DC and TD groups, respectively.

Total cholesterol fractions (Fig. 2d) were reduced by $31.72 \%(p=0.0041), 27.91 \%(p \leq 0.05)$, and $28.61 \%(p \leq$ $0.05)$ in the TD $(107.4 \pm 12.09 \mathrm{mg} / \mathrm{dL}), \mathrm{SD}(113.4 \pm 15$, $46 \mathrm{mg} / \mathrm{dL})$, and TSD $(112.3 \pm 11.28 \mathrm{mg} / \mathrm{dL})$ groups, respectively, compared to the DC group (157.3 $\pm 34.47 \mathrm{mg} /$ $\mathrm{dL})$. However, no significant differences occurred among the TD, SD, and TSD groups.
The lactate dehydrogenase concentration was evaluated (Fig. 2e), and there were no significant differences displayed among the DC $(295.8 \pm 84.18 \mathrm{UI} / \mathrm{L})$, TD $(231.7 \pm 51.05 \mathrm{UI} / \mathrm{L}), \mathrm{SD}(211.2 \pm 79.32 \mathrm{UI} / \mathrm{L})$, and TSD $(208.8 \pm 20.36 \mathrm{UI} / \mathrm{L})$ groups.

Figure $2 \mathrm{f}$ illustrates the plasma creatine kinase concentration. A decrease of $43.58 \%(p=0.0016)$ was detected in the TSD group $(422,5 \pm 145.1 \mathrm{UI} / \mathrm{L})$ compared to the TD group $(748.9 \pm 116 \mathrm{UI} / \mathrm{L})$. However, no significant differences occurred between the DC group $(280.0 \pm 38.24 \mathrm{UI} /$ $\mathrm{L}, p=0.2598)$ and the SD group $(229.9 \pm 95.25 \mathrm{UI} / \mathrm{L})$.

Regarding plasma reactive species markers (Fig. 3a), the TD group $(299.7 \pm 35.12 \mathrm{nMolEq} / \mathrm{mL}, p=0.0126)$ showed a $24.72 \%$ increase in the concentration of thiobarbituric acid reactive substances (TBARS) compared to the DC group $(240.3 \pm 78.85 \mathrm{nMolEq} / \mathrm{mL})$. There was no significant difference between the DC and SD groups $(216.5 \pm 33.55 \mathrm{nMolEq} / \mathrm{mL})$; however, the SD and TSD 


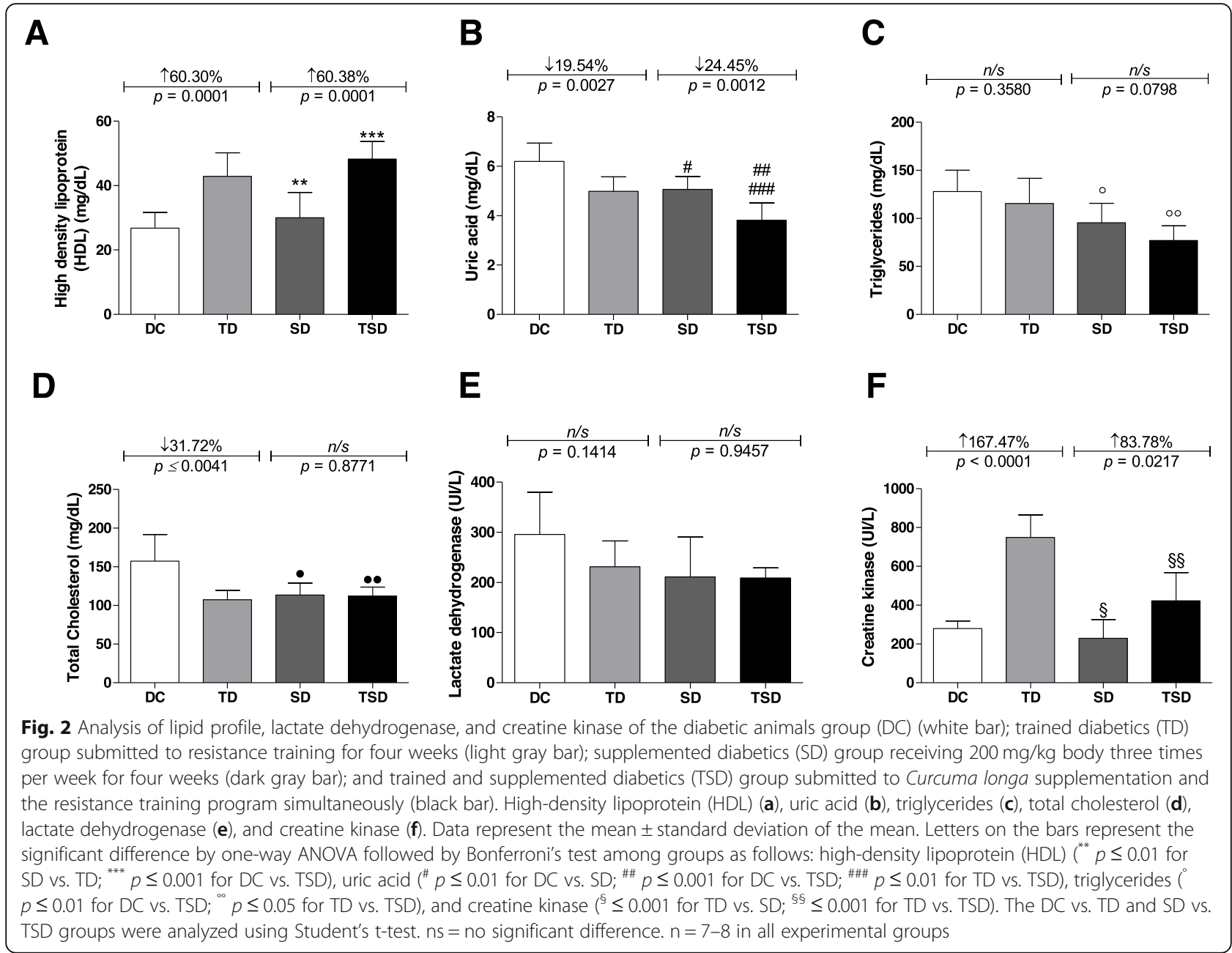

$(175.6 \pm 23.40 \mathrm{nMolEq} / \mathrm{mL})$ groups showed a decrease of $27.76 \%(p \leq 0.01)$ and $41.41 \%(p \leq 0.001)$ in the TBARS concentration, respectively, when compared to the TD group. When the value of the concentration of thiobarbituric acid reactive substances (TBARS) of the TSD group was compared with that of the $\mathrm{DC}$ and $\mathrm{SD}$ groups, there was a reduction of $26.92 \%(p \leq 0.01)$ and $18.90 \%(p=0.0006)$, respectively.

Figure $3 \mathrm{~b}$ illustrates the TBARS marker in the liver tissue; there was a $19.58 \%(p=0.0014)$ increase in the TD group $(710.8 \pm 93.28 \mathrm{nMolEq} /$ gram tissue) compared to the DC group (594.4 $\pm 123.9 \mathrm{nMolEq} / \mathrm{gram}$ tissue). However, no significant differences were found between the DC, SD $(520.0 \pm 227.3 \mathrm{nMolEq} /$ gram tissue $)$, and TSD $(492.0 \pm \mathrm{nMolEq} / \mathrm{gram}$ tissue) groups. There was a similar effect between the SD and TSD $(p=0.06064)$ groups, but the SD and TSD groups showed a reduction of $26.84 \%(p \leq 0.001)$ and $30.78 \%(\mathrm{p} \leq 0.01)$, respectively, in the TBARS concentrations when compared with the TD group. The effect in the TSD group, however, was similar to that of the DC group.
Figure 3c shows the concentration of TBARS in the pancreas, where a $45.53 \%(p<0.0001)$ reduction in TBARS was observed in the TD group $(322.3 \pm 110.6$ nMolEq/gram tissue) compared to the DC group ( $591.7 \pm 198.5 \mathrm{nMolEq} /$ gram tissue). The comparison between the SD (319.8 $\pm 145.5 \mathrm{nMolEq} /$ gram tissue $)$ and TSD (324.0 $\pm 75.24 \mathrm{nMolEq} / \mathrm{g}$ tissue) groups did not differ $(p=0.5857)$. However, the SD and TSD groups showed a reduction of $48.84 \%(p \leq 0.001)$ and $46.22 \%$ $(\mathrm{p} \leq 0.001)$, respectively, in the TBARS concentrations when compared to the DC group. The effects in the TD, SD, and TSD groups were similar to each other.

The results of TBARS in cardiac tissue are depicted in Fig. 3d. In the TD $(237.9 \pm 78.45 \mathrm{nMolEq} /$ gram tissue $)$, SD $(246.9 \pm 79.63 \mathrm{nMolEq} /$ gram tissue), and TSD $(220.7 \pm 57.23 \mathrm{nMolEq} / \mathrm{gram}$ tissue) groups, reductions of $51.85 \%(p \leq 0.001), 50.03 \%(p \leq 0.001)$, and $55.33 \%$ $(p \leq 0.001)$, respectively, were observed when compared with the DC group (494.1 $\pm 108.2 \mathrm{nMolEq} /$ gram tissue). There were no significant differences when comparing the TD, SD, and TSD groups with each other. 


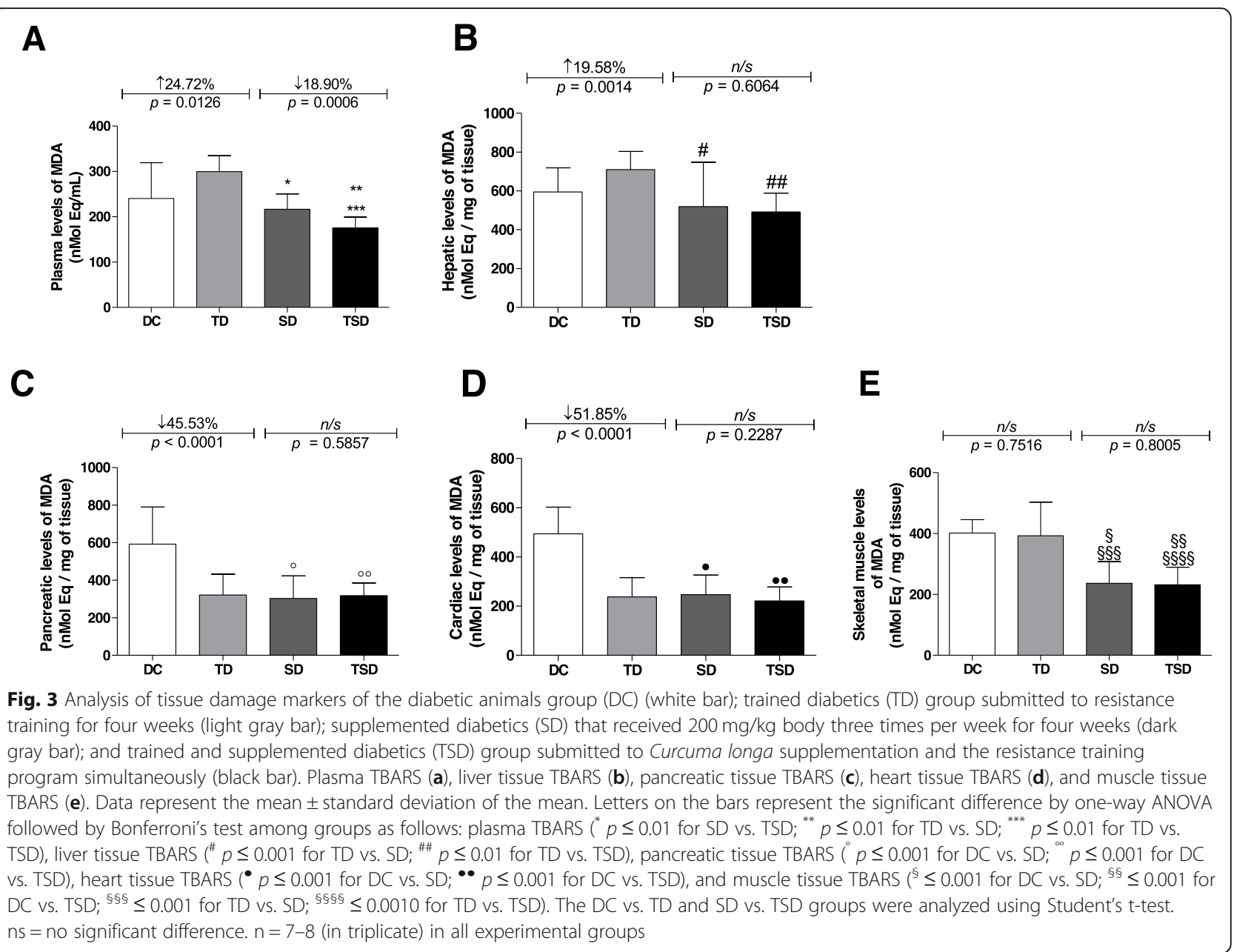

The TBARS concentrations in skeletal muscle tissue (Fig. 3e) were similar in the DC $(401.2 \pm 44.57 \mathrm{nMolEq} /$ gram tissue) and TD $(392.9 \pm 110.5 \mathrm{nMolEq} / \mathrm{g}$ tissue $)$ groups $(p=0.7516)$; the SD $(236.7 \pm 70.84 \mathrm{nMolEq} /$ gram tissue) and TSD (231.6 $\pm 57.62 \mathrm{nMolEq} /$ gram tissue $)$ groups also showed no significant difference between them $(p=0.8005)$. However, the SD group showed a reduction of $39.76 \%$ ( $\mathrm{p} \leq 0.001)$ compared to the TD group (Fig. 3f). The results show that there was a reduction of $41.05 \%(\mathrm{p} \leq 0.001)$ and $42.27 \%(\mathrm{p} \leq 0.001)$ in the TSD group when compared to the TD and DC groups, respectively. There was also a reduction of $41.00 \%$ in the SD group compared to the DC $(p<0.001)$ group.

\section{Discussion}

The present study aimed to evaluate moderate- to high-intensity RTP-associated Curcuma longa supplementation and its effects on weight gain, recovery, glycemic control, muscle damage, and reactive species markers in alloxan-induced type- 1 diabetic rats. The use of alloxan in an experimental model causes a similar picture as in some humans with type 1 diabetes without blood glucose control, involving symptoms such as polydipsia and polyphagia and a marked reduction in body weight [34, 38, 39].

The animals from the DC group showed a significant reduction in body weight throughout the experiment. This symptom is due to the effects of untreated T1DM in chronic conditions (without insulin therapy), which among its effects is evidence of exacerbated protein and lipid catabolism associated with glycosuria and polyuria $[40,41]$. However, the TD, SD, and TSD groups presented attenuation of body weight reduction. The beneficial effect of Curcuma longa supplementation (SD groups) on body weight was similar to the results from other authors [42].

According to the American Diabetes Association [43], glycemic alterations over a long period of time cause numerous metabolic dysfunctions, among which the most common are autonomic peripheral neuropathies, retinopathy, ketoacidosis, and nonketotic hyperosmolar syndrome.

In patients with T1DM, the plasma glucose concentration must be maintained under conditions close to the 
ideal values (when the baseline result is equal to or above $126 \mathrm{mg} / \mathrm{dL}$ and the oral glucose tolerance test is at or above $200 \mathrm{mg} / \mathrm{dL}$, the disease is proven) to attenuate the development of metabolic diseases such as retinopathy, limb amputation, and dyslipidemia [2, 43]. Supplementation with Curcuma longa for 21 days in supplemented type 1 diabetic rats was able to promote a marked reduction in the blood glucose concentration [44]. This effect was similar to our study, which showed that supplementation of turmeric at a dosage of $200 \mathrm{mg} /$ $\mathrm{kg}$ body weight can attenuate plasma glucose.

Both resistance training and Curcuma longa supplementation showed a hypoglycemic effect throughout the treatment, as there was a reduction in the blood glucose in the experimental groups TD, SD, and TSD. Although the RTP protocol alone promoted a reduction in blood glucose, it was even greater with the combination of RTP associated with Curcuma longa supplementation. However, no differences were observed when comparing the TD, SD, and TSD groups.

The glucose-lowering effects of $\mathrm{CL}$ supplementation and exercise in the complete absence of any residual insulin observed in the present study may elicit novel insulin-independent glucose-lowering pathways in T1DM and should be a matter of further investigation.

RTP is able to provide beneficial effects on patients with diabetes, as it can promote increased glucose uptake in skeletal muscles. This effect is partly due to the possibly increased GLUT-4 translocation and the beneficial adjustment of the insulin-independent glucose uptake pathway $[16-19,45]$. Curcumin is effective in the prevention and control of diabetes since it helps to reduce the concentration of glycated hemoglobin and, consequently, controls plasma glucose by mechanisms that are not yet fully understood [46-48].

The severe hyperglycemia in uncontrolled T1DM results in a low input of tissue and cellular energy substrate. As a consequence, it causes suppression of ATP genesis and the activation of pathways involved in the formation of ROS [49, 50].

Some authors suggested that when glucose and free fatty acids are increased in the blood, they may activate molecular mechanisms in different cellular types. This scenario involves electron transport overload, increased formation of metabolic byproducts, electron leak, ROS generation, and upregulation of inflammatory signaling [9]. We hypothesize that supplementation with Curcuma longa may play an important role in ROS production by mechanisms that are not yet known.

Experimental diabetes also shows hypertriglyceridemia in animals treated with alloxan [51]; during T1DM, untreated animals showed enhanced fatty acid release by adipose tissues during ketosis. In our studies, the results were similar; sedentary diabetic animals (DC) showed increased concentrations of triglycerides and total cholesterol compared to SD and TSD, respectively. These effects are partly due to disease progression caused by the imbalance of some of the macrovascular and microvascular risk factors [43].

Thus, supplementation with RTP-associated Curcuma longa for four weeks has been shown to effectively improve the lipid profile of diabetic animals, resulting in reductions in the total cholesterol and triglyceride concentrations and an increase in HDL. Our results corroborate the results of $\mathrm{Su}$ et al. [52], who used curcumin supplementation for eight weeks and found a reduction in the concentration of high-intensity lipoprotein cholesterol (LDL-C) and triglycerides and an increase in the concentration of high-intensity lipoprotein (HDL-C). In addition, this effect of Curcuma longa (CL) supplementation on the body is maintained over time. According to another study, supplementation with $1000 \mathrm{mg}$ /day of Curcuma longa for 12 weeks is also able to promote a reduction in total serum cholesterol (TC), LDL-C, and triglycerides and cause an increase in HDL-C [46]. Despite this evidence, more studies are necessary to clarify this effect of CL supplementation on the lipid profile.

In healthy organisms, more specifically in their cells, the high concentration of free radicals is temporary because the body is able to activate the antioxidant defense system. However, a constant metabolic imbalance between the increased concentration of reactive species and the decreased concentration and/or activity of antioxidant molecules characterizes an organic and metabolic condition called oxidative stress, which is associated with numerous pathologies, including diabetes mellitus [53].

Studies have shown a significant increase in reactive species associated with physical exercise with maximal and supramaximal intensities [54-57]. Exercise-induced tissue stress causes the recruitment and migration of leukocytes and cells from the immune system to the damaged area, which is proportional to the exercise intensity $[58,59]$.

Some authors suggest that physical exercise is capable of inducing tissue damage; these effects are partly due to reactive species markers caused by the increased concentration of CK, LDH, and malonaldehyde markers [34, 60]. However, it is noteworthy that this increase will depend on the mode, intensity, and duration of the physical training. In addition, the oscillation of these parameters is an adaptive response of the body to moderate exercise and is beneficial to health [61].

Reactive species can be triggered by a number of factors, including increased metabolism of prostanoids, xanthine oxidase, and NADPH oxidase enzymes, oxidation of purine bases and iron-containing proteins, and disruption of $\mathrm{Ca}^{2+}$ homeostasis $[62,63]$. 
The present research showed that moderate- to high-intensity resistance training induced tissue injury when there was a significant increase in CK and plasma $\mathrm{LDH}$ concentrations in the group of trained diabetic animals. However, we were not able to determine whether these changes remained after the training had ended. In the present research, the animals from the SD and TSD groups that were treated with Curcuma longa supplementation and underwent resistance physical training presented a significant reduction in the markers of CK, ALT, and uric acid; however, we did not observe reductions in the AST and LDH concentrations.

Corroborating these results with an experimental model, in the study by Tanabe et al. [64], where oral supplementation of Curcuma $180 \mathrm{mg}$ was used in humans for seven days before and after isokinetic eccentric exercise, positive effects were noted on the inflammatory and muscle damage markers, presenting a reduction in CK activity with supplementation between 3 and 6 days before exercise and 5 to 7 days after exercise. Therefore, these results demonstrate that Curcuma longa supplementation associated with physical exercise can be effective in mitigating reactive species production.

In addition, tissue damage caused by high-intensity RTP can be reduced with the use of medicinal plants containing polyphenols and antioxidants such as vitamins A, E, and C [65-69].

Supplementation with antioxidants is capable of modulating the redox state of cells and counteracting the deleterious effects caused by ROS, with the possibility of reversing and/or attenuating lipid peroxidation caused by reactive species [70].

$\mathrm{DM}$ is a condition associated with increased free radicals due to the increased production of the TBARS marker in various tissues [71, 72]. Thus, this research aimed to elucidate the effects of Curcuma longa supplementation and its possible protective effect on reactive species markers in organs such as the pancreas, liver, heart, and skeletal muscle of diabetic animals.

In the liver tissue, Curcuma longa supplementation reduced the TBARS concentrations, showing positive effects on lipid oxidation when compared to the group of diabetic animals without any treatment. Reductions in the TBARS concentrations in the SD and TSD groups confirmed that RTP and the supplementation results in the control of reactive species markers, which may explain the decrease in the plasma glucose concentration in these experimental groups.

The pancreas is an organ susceptible to oxidative stress and damage caused by the increased concentration of reactive species under altered metabolic conditions $[73,74]$. In general, type 1 diabetes (T1DM) is characterized by inflammation of the pancreatic islets, associated with increased free radical species, proinflammatory cytokines, and immune cell migration with specific $\beta$-cell antibodies, leading to $\beta$-cell dysfunction and cellular death [8,9]. Consequently, enhanced islet $\alpha$-cell activity leads to a hyperglucagonemia state that enhances hepatic glucose production by the action of this hormone $[2,9,75]$. In our study, we found a decrease in the concentration of TBARS in the pancreas in the TD, SD, and TSD groups. Thus, both physical training and supplementation were able to attenuate the deleterious effects of diabetes on this organ.

Both T1DM and T2DM present as a highly inflammatory and oxidative pathology, presenting a direct relation to cardiovascular events. In nondrug therapy, the use of antioxidants and phenolic compounds shows positive effects on redox action and has a protective effect on the heart tissue and prevents damage to it [76-78]. In the present study, both resistance training and supplementation and their combination demonstrated protective effects against the damage caused by reactive species to the cardiac tissue in T1DM.

Thus, supplementation with Curcuma longa associated with RTP was able to provide body weight recovery, reduce glycemic rates, and attenuate reactive species production and tissue damage caused by hyperglycemia when compared to controls or physical activity alone.

\section{Conclusion}

In summary, the use of Curcuma longa associated with the RTP protocol is able to attenuate weight loss in chronic metabolic conditions caused by T1DM, which is associated with reduced blood glucose and lipid parameters. These effects are partly due to the reduced activity of some reactive species markers associated with moderate- to high-intensity resistance training, and the content of some T1DM-induced tissue injury marker enzymes were significantly reduced. Therefore, physical training associated with Curcuma longa represents a potential nonpharmacological therapeutic alternative in the treatment of T1DM.

Despite these results, it is certainly not sufficient. Lipid peroxidation is a complex process, as mentioned even by other authors $[78,79]$, and we suggest that further investigations should be made to detect what molecule(s) is involved in lipid peroxidation.

We hypothesize that even without insulin use for T1DM, exercise alone or in association with CL was able to promote adjustments that resulted in a reduction in blood glucose levels, attenuation of the activation of systemic inflammation and attenuation of the recruitment of immune cells, typically caused by uncontrolled T1DM. Glucose improvement irrespective of insulin and 
under undetectable insulin levels is a novel mechanism that is possibly mediated by reactive oxygen speciesdependent pathways $[8,9]$. However, these findings as well as the underlying mechanisms should be investigated.

In addition, we advocate that the influence of diet on physical activity parameters is not discarded, as is well documented by other authors [80, 81], and it is necessary in future studies to analyze the interaction of diet on physical activity parameters considering individual characteristics to guarantee the correct ingestion of antioxidant supplementation and their beneficial effects on the whole body [33].

\begin{abstract}
Abbreviations
DM: Diabetes mellitus (DM); CL: Curcuma longa; T1DM: Type 1 diabetes mellitus; DC: Sedentary diabetic rats; TD: Diabetic rats that underwent a 4week resistance training protocol; SD: CL-supplemented diabetic rats; TSD: Supplemented diabetic rats that underwent the same conditions as above; HDL: High-density lipoprotein; ALT: Alanine aminotransferase; AST: Aspartate aminotransferase; CK: Creatine kinase; LDH: Lactate dehydrogenase; TBARS: Thiobarbituric acid reactive substances; ROS: Reactive oxygen species; GLUT-4: Glucose transporter 4.; CEPA: Ethics Committee on Animals; RTP: Resistance training protocol; KCL: Potassium chloride solution ATP: Adenosine triphosphate; NADPH: Chemically reduced form of NADP
\end{abstract}

\section{Acknowledgments}

We thank American Journal Experts (AJE) and to Igor Araujo Santos Trindade for English language editing.

\section{Authors' contributions}

Conceptualization: ASSJ. Data curation: ASSJ, FJA, AMOS, and JLdosS. Formal analysis: ASSJ and ACM. Investigation: ASSJ, FJA, AMOS, JDMS, and JLdosS. Methodology: ASSJ, JDMS, JLdosS, SSA, and CSE. Project administration: ASSJ. Writing - original draft: ASSJ. Writing - review \& editing: FJA, AMOS, JLdosS, SSA, CSE, FBL, and ACM. All authors have read and approved the manuscript.

\section{Funding}

We thank the support of the Fundação de Apoio à Pesquisa e à Inovação Tecnológica do Estado de Sergipe - FAPITEC/SE for granting research grants to ASSJ and for supporting the publication of this work, however, had no role in the design, analysis, or writing of this article.

\section{Availability of data and materials}

The datasets used and/or analysed during the current study available from the corresponding author on reasonable request.

\section{Ethics approval and consent to participate}

The Animal Research Ethics Committee approved all the processes undertaken in the methodology of the present study. (CEPA Protocol 72/18).

\section{Consent for publication}

Not Applicable.

\section{Competing interests}

None.

\section{Author details}

'Department of Physical Education, Universidade Federal de Sergipe, São Cristóvão, Sergipe, Brazil. ${ }^{2}$ Group of Studies and Research of Performance, Sport, Health and Paralympic Sports - GEPEPS, Universidade Federal de Sergipe, São Cristóvão, Sergipe, Brazil. ${ }^{3}$ Department of Physiology, Universidade Federal de Sergipe, São Cristóvão, Sergipe, Brazil. ${ }^{4}$ Department of Nutrition, Universidade Federal de Sergipe, São Cristóvão, Sergipe, Brazil. ${ }^{5}$ Department of Physiology and Biophysics, Universidade de São Paulo, São Paulo, Brazil. ${ }^{6}$ Department of Morphology, Universidade Federal de Sergipe, São Cristóvão, Sergipe, Brazil.
Received: 19 November 2019 Accepted: 22 July 2020

Published online: 06 August 2020

\section{References}

1. International Diabetes Federation. IDF Diabetes Atlas. 9th ed. Brussels; 2019. Available from: https://www.diabetesatlas.org.

2. American Diabetes Association, et al. Diabetes Care. 2012;35(Suppl.1):S1163. https://doi.org/10.2337/dc12-s011.

3. Sociedade Brasileira de Diabetes. Diretrizes da Sociedade Brasileira de Diabetes (2019-2020). São Paulo: Clanad; 2019. Avaliable from: https://www. diabetes.org.br/profissionais/images/DIRETRIZES-COMPLETA-2019-2020.pdf.

4. Palacios OM, Kramer M, Maki KC. Diet and prevention of type 2 diabetes mellitus: beyond weight loss and exercise. Expert Rev Endocrinol Metab. 2019;14(1):1-12. https://doi.org/10.1080/17446651.2019.1554430.

5. Alberti KGMM, Eckel RH, Grundy SM, Zimmet PZ, Cleeman II, Donato KA, et al. Harmonizing the metabolic syndrome: a joint interim statement of the International Diabetes Federation task force on Epidemiology and Prevention; National Heart, Lung, and Blood Institute; American Heart Association; World Heart Federation; International Atherosclerosis Society; and International Association for the Study of Obesity. Circ. 2019;120(16): 1640-5. https://doi.org/10.1161/CIRCULATIONAHA.109.192644.

6. American Diabetes Association. Management of diabetes in pregnancy: standards of medical care in diabetes - 2019. Diabetes Care. 2019; 42(Suppl.1):S165-72. https://doi.org/10.2337/dc19-S014.

7. Bódis K, Kahl S, Simon MC, Zhou Z, Sell H, Knebel B, et al. Reduced expression. Of stearoyl-CoA desaturase-1, but not free fatty acid receptor 2 or 4 in subcutaneous adipose tissue of patients with newly diagnosed type 2 diabetes mellitus. Nutr Diabetes. 2018;8(1):49-57. https://doi.org/10.1038/ s41387-018-0054-9.

8. Zhang P, Li T, Wu X, Nice EC, Huang C, Zhang Y. Oxidative stress and diabetes: antioxidative strategies. Front Med. 2020;4:1-18. https://doi.org/10. 1007/s11684-019-0729-1.

9. Newsholme P, Keane KN, Carlessi R, Cruzat V. Oxidative stress pathways in pancreatic $\beta$-cells and insulin-sensitive cells and tissues: importance to cell metabolism, function, and dysfunction. Am J Physiol Cell Physiol. 2019 Sep 1;317(3):C420-33. https://doi.org/10.1152/ajpcell.00141.2019.

10. Tao B, Pietropaolo M, Atkinson M, Schatz D, Taylor D. Estimating the cost of type 1 diabetes in the U.S.: a propensity score matching method. PLoS One. 2010;5(7):e11501. Published 2010 Jul 9. https://doi.org/10.1371/journal.pone. 0011501.

11. Giorda CB, Rossi MC, Ozzello O, Gentile S, Aglialoro A, Chiambretti A, Baccetti F, Gentile FM, Romeo F, Lucisano G. Nicolucci a; HYPOS-1 study group of AMD. Healthcare resource use, direct and indirect costs of hypoglycemia in type 1 and type 2 diabetes, and nationwide projections. Results of the HYPOS-1 study. Nutr Metab Cardiovasc Dis. 2017;27(3):209-16. https://doi.org/10.1016/..numecd.2016.10.005.

12. Bru-Tari E, Cobo-Vuilleumier N, Alonso-Magdalena P, Santos RS, Marroqui L, Nadal A, et al. Pancreatic alpha-cell mass in the early-onset and advanced stage of a mouse model of experimental autoimmune diabetes. Sci Rep. 2019;9(1):9515. https://doi.org/10.1038/s41598-019-45853-1.

13. Dirice E, Kahraman S, De Jesus DF, El Quaamari A, Basile G, Baker RL, et al. Increased $\beta$-cell proliferation before immune cell invasion prevents progression of type 1 diabetes. Nat Metab. 2019;1(5):509-18. https://doi.org/ 10.1038/s42255-019-0061-8.

14. Imam S, Prathibha R, Dar P, Almotah K, Al-Khudhair A, Hasan AS, et al. elF5A inhibition influences $T$ cell dynamics in the pancreatic microenvironment of the humanized mouse model of type 1 diabetes. Sci Rep. 2019;9(1):1533-48. https://doi.org/10.1038/s41598-018-38341-5.

15. Haslacher H, Fallmann H, Waldhäusl C, Hartmann E, Wagner OF, Waldhäus W. Type 1 diabetes care: improvement by standardization in a diabetes rehabilitation clinic. an observational report. PloS One. 2018;13(3):e0194135. https://doi.org/10.1371/jornal.pone.0194135.

16. Wu N, Bredin SSD, Guan Y, Dickinson K, Kim DD, Chua Z, et al. Cardiovascular health benefits of exercise training in persons living with type 1 diabetes: a systematic review and meta-analysis. J Clin Med. 2019; 8(2):253-79. https://doi.org/10.3390/jcm8020253.

17. Cadegiani FA, Diniz GC, Alves G. Aggressive clinical approach to obesity improves metabolic and clinical outcomes and can prevent bariatric surgery: a single center experience. BMC Obes. 2017;21:4-9. https://doi.org/ 10.1186/s40608-017-0147-3. 
18. Turgut M, Cinar V, Pala R, Tuzcu M, Orhan C, Telceken H, et al. Biotin and chromium histidinate improve glucose metabolism and proteins expression levels of IRS-1, PPAR- $\gamma$, and NF-KB in exercise-trained rats. J Int Soc Sports Nutr. 2018;15(1):45-54. https://doi.org/10.1186/s12970-018-0249-4.

19. Santos JL, Araujo SS, Estevam CS, Lima CA, Carvalho CRO, Lima FB, et al. Molecular mechanisms of muscle glucose uptake in response to resistance exercise: a review. J Exerc Physiol Online. 2017;20(4):200-11.

20. Klip A, McGraw TE, James DE. Thirty sweet years of GLUT4. J Biol Chem. 2019 July;294(30):11369-81. https://doi.org/10.1074/jbc.rev119.008351.

21. Böhm A, Weigert C, Staiger H, Häring HU. Exercise and diabetes: relevance and causes for response variability. Endocr. 2016 March;51(3):390-401. https://doi.org/10.1007/s12020-015-0792-6

22. Fayh APT, Borges K, Cunha GS, Krause M, Rocha R, Bittencourt PIH Jr, et al. Effects of $n-3$ fatty acids and exercise on oxidative stress parameters in type 2 diabetic: a randomized clinical trial. J Int Soc Sports Nutr. 2018;15(1):18-26 https://doi.org/10.1186/s12970-018-0222-2.

23. Vargas S, Romance R, Petro JL, Bonilla DA, Galancho I, Espinar S, et al. Efficacy of ketogenic diet on body composition during resistance training in trained men: a randomized controlled trial. J Int Soc Sports Nutr. 2018;15(1): 31-9. https://doi.org/10.1186/s12970-018-0236-9.

24. Marchi JP, Tedesco L, Melo AC, Frasson AC, França VF, Sato SW, et al. Cúrcuma longa L., o açafrão da terra, e seus benefícios medicinais. Arq. Ciências Saúde UNIPAR. 2016 Dec;20(3):189-94. doi: https://doi.org/10. 25110/arqsaude.v20i3.2016.5871.

25. Lai $X$, Tong D, Ai X, Wu J, Luo Y, Zuo F, et al. Amelioration of diabetic nephropathy in $\mathrm{db} / \mathrm{db}$ mice treated with tibetan medicine formula Siwei Jianghuang decoction powder extract. Sci Rep. 2018;8(1):16707-17. https:// doi.org/10.1038/s41598-018-35148-2.

26. Niu Y, He J, Ahmad H, Wang C, Zhong X, Zhang L, et al. Curcumin attenuates insulin resistance and hepatic lipid accumulation in a rat model of intrauterine growth restriction through insulin signaling pathway and SREBPs. Br J Nutr. 2019;25:1-2. https://doi.org/10.1017/S0007114519001508.

27. Kumar $A B$, Dora J, Singh $A$. A review on spice of life Curcuma longa (turmeric). Int J Appl Biol Pharm. 2011;2(4):371-9.

28. Gera M, Sharma N, Ghosh M, Huynh DL, Lee SJ, Min T, et al. Nanoformulations of curcumin: an emerging paradigm for improved remedial application. Oncotarget. 2017:8(39):66680-98. https://doi.org/10. 18632/oncotarget.19164.

29. Chashmiam S, Mirhafez SR, Dehabeh M, Hariri M, Azimi Nezhad M, Nobakht MGBF. A pilot study of the effect of phospholipid curcumin on sérum metabolomic profile in patients with non-alcoholic fatty liver disease: a randomized, double-blind, placebo-controlled trial. Eur J Clin Nutr. 2019;73: 1224-35. https://doi.org/10.1038/s41430-018-0386-5.

30. Zhang J, Xu L, Zhang L, Ying Z, Su W, Wang T. Curcumin attenuates $d$ galactosamine/lipopolysaccharide-induced liver injury and mitochondrial dysfunction in mice. J Nutr. 2014;144(8):1211-8. https://doi.org/10.3945/jn. 114.193573.

31. He J, Niu Y, Wang F, Cui T, Bai K, Zhang J, et al. Dietary curcumin supplementation attenuates inflammation, hepatic injury and oxidative damage in a rat model of intra-uterine growth retardation. Br J Nutr. 2018; 120(5):537-48. https://doi.org/10.1017/S0007114518001630.

32. Margaritelis NV, Paschalis V, Theodorou AA, Kyparos A, Nikolaidis MG. Redox basis of exercise physiology. Redox Biol. 2020;10:101499. https://doi.org/10. 1016/j.redox.2020.101499.

33. Margaritelis NV, Paschalis V, Theodorou AA, Kyparos A, Nikolaidis MG. Antioxidants in Personalized Nutrition and Exercise. Adv Nutr. 2018;9(6):81323. https://doi.org/10.1093/advances/nmy052.

34. Santos JL, Dantas RE, Lima CA, Araujo SS, Almeida EC, Marçal AC, Estevam C. dos S. protective effect of a hydroethanolic extract from Bowdichia virgiliiodes on muscular damage and oxidative stress caused by strenuous resistance training in rats. J Int Soc Sports Nutr. 2014;11(1):58-68. https://doi. org/10.1186/s12970-014-0058-3

35. Tamaki T, Uchiyama S, Nakano S. A weightlifiting exercise model for inducing hypertrophy in the hindlimb muscles of rats. Med Sci Sports Exerc. 1992;24(8):881-6.

36. Barauna VG, Batista ML Jr, Costa Rosa LF, Casarini DE, Krieger JE, Oliveira EM Cardiovascular adaptations in rats submitted to a resistance-training model. Clin Exp Pharmacol Physiol. 2005;32(4):249-54. https://doi.org/10.1111/j. 14440-1681.2005.04180.x

37. Lapenna D, Ciofani G, Pierdomenico SD, Giamberardino MA, Cuccurullo F. Reaction conditions affecting the relationship between thiobarbituric acid reactivity and lipid peroxides in human plasma. Free Rad Biol Med. 2001; 31(1):331-5. https://doi.org/10.1016/s0891-5849(01)00584-6.

38. Brito-Casillas Y, Melián C, Wagner AM. Study of the pathogenesis and treatment of diabetes mellitus through animal models. Endocrinol Nutr. 2016;63(7):345-53. https://doi.org/10.1016/j.endonu.2016.03.011.

39. Ighodaro OM, Adeosun AM, Akinloye AO. Alloxan-induced diabetes, a common model for evaluating the glycemic-control potential of therapeutic compounds and plants extracts in experimental studies. Medicina (Kaunas). 2017;53(6):365-74. https:/doi.org/10.1016/j.medici.2018.02.001.

40. Vakilian M, Tahamtani Y, Ghaedi K. A review on insulin trafficking and exocytosis. Gene. 2019;706:52-61. https://doi.org/10.1016/j.gene.2019.04.063.

41. Dhanavathy G. Immunohistochemistry, histopathology, and biomarker studies of swertiamarin, a secoiridoid glycoside, prevents and protects streptozotocin-induced $\beta$-cell damage in Wistar rat pancreas. J Endocrinol Investig. 2015;38(6):669-84. https://doi.org/10.1007/s40618-015-0243-5.

42. Yang F, Yu J, Ke F, Lan M, Li D, Tan K, et al. Curcumin alleviates diabetic retinopathy in experimental diabetic rats. Ophthalmic Res. 2018;60(1):43-54. https://doi.org/10.1159/000486574.

43. American Diabetes Association. Standards of medical care in diabetes. Diabetes Care. 2014;37(Suppl.1):S14-80. https://doi.org/10.2337/dc14-S014.

44. Xie Z, Wu B, Shen G, Li X, Wu Q. Curcumin alleviates liver oxidative stress in type 1 diabetic rats. Mol Med Rep. 2018;17(1):103-8. https://doi.org/10.3892/ mmr.2017.7911.

45. Yardley JE, Kenny GP, Perkins BA, Riddell MC, Goldfield GS, Donovan L, et al. Resistance exercise in already-active diabetic individuals (READI): study rationale, design and methods for a randomized controlled trial of resistance and aerobic exercise in type 1 diabetes. Contemp Clin Trials. 2015;41:129-38. https://doi.org/10.1016/j.cct.2014.12.017.

46. Panahi Y, Hosseini MS, Khalili N, Naimi E, Majeed M, Sahebkar A. Antioxidant and anti-inflammatory effects of curcuminoid-piperine combination in subjects with metabolic syndrome: a randomized controlled trial and an updated meta-analysis. Clin Nutr. 2015;34(6):1101-8. https://doi.org/10.1016/ j.clnu.2014.12.019.

47. Alonso JR. Treatment of phytochemistry and nutraceuticals. 3rd ed. Brazil: Pharmabooks; 2016.

48. Panahi $Y$, Khalili N, Sahebi E, Namazi S, Simental-Mendía LE, Majeed M, et al. Effects of curcuminoids plus piperine on glycemic, hepatic and inflammatory biomarkers in patients with type 2 diabetes mellitus: a randomized double-blind placebo-controlled trial. Drug Res. 2018;68(7):4039. https://doi.org/10.1055/s-0044-101752.

49. Shah MS, Brownlee M. Molecular and cellular mechanisms of cardiovascular disorders in diabetes. Circ Res. 2016;118(11):1808-29. https://doi.org/10. 1161/CIRCRESAHA.116.306923.

50. Ighodaro OM. Molecular pathways associated with oxidative stress in diabetes mellitus. Biomed Pharmacother. 2018;108:656-62. https://doi.org/ 10.1016/j.biopha.2018.09.058.

51. Leme JA, Gomes RJ, Mello MA, Luciano E. Effects of short-term physical training on the liver IGF-I in diabetic rats. Growth Factors. 2007;25(1):9-14. https://doi.org/10.1080/089771907012106937.

52. Su LQ, Wang YD, Chi HY. Effect of curcumin on glucose and lipid metabolism, FFAs and TNF-a in serum of type 2 diabetes mellitus rat models. Saudi J Biol Sci. 2017;24(8):1776-80. https://doi.org/10.1016/j.sjbs. 2017.11.011.

53. Arcego DM, Krolow R, Lampert C, Noschang C, Ferreira AG, Scherer E, et al. Isolation during the prepubertal period associated with chronic access to palatable diets: effects on plasma lipid profile and liver oxidative stress. Physiol Behav. 2014;124:23-32. https://doi.org/10.1016/j.physbeh.2013.10.029.

54. Hellsten Y, Apple FS, Sjödin B. Effect of sprint cycle training on activities of antioxidant enzymes in human skeletal muscle. J Appl Physiol. 1996;81(4): 1484-7. https://doi.org/10.1152/jappl.1996.81.4.1484.

55. Groussard C, Machefer G, Rannou F, Faure H, Zouhal H, Sergent O, et al. Physical fitness and plasma non-enzymatic antioxidant status at rest and after a Wingate test. Can J Appl Physiol. 2003;28(1):79-92. https://doi.org/10. 1139/h03-007\#.XXaxxndFzIU.

56. Finaud J, Lac G, Filaire E. Oxidative stress: relationship with exercise and training. Sports Med. 2006;36(4):327-58. https://doi.org/10.2165/00007256200636040-00004

57. Cruzat VF, Rogero MM, Borges MC, Tirapegui J. Current aspects about oxidative stress, physical exercise and supplementation. Rev Bras Med Esporte. 2007;13(5):336-42. https://doi.org/10.1590/S151786922007000500011. 
58. Hawke TJ. Muscle stem cell and exercise training. Exerc Sport Sci Rev. 2005; 33(2):63-8. https://doi.org/10.1097/00003677-200504000-00002.

59. Saxton JM, Claxton D, Winter E, Pockley AG. Peripheral blood leucocyte functional responses to acute eccentric exercise in humans are influenced by systemic stress, but not by exercise-induced muscle damage. Clin Sci (Lond). 2003;104(1):69-77. https://doi.org/10.1042/cs1040069.

60. Peterneli TT, Coombes JS. Antioxidant supplementation during exercise training: beneficial or detrimental? Sports Med. 2011;41(12):1043-69. https:// doi.org/10.2165/11594400-000000000-00000

61. Pingitore A, Lima GP, Mastorci F, Quinones A, lervasi G, Vassalle C. Exercise and oxidative stress: potential effects of antioxidant dietary strategies in sports. Nutr. 2015 July-Aug;31(7-8):916-22. https://doi.org/10.1016/j.nut. 2015.02.005.

62. Urek RO, Kayali HÁ, Tarhan L. Characterization of the antioxidant properties of seeds and skins in selected Turkish grapes. Asian J Chem. 2008;20(5): 3750-62.

63. Tongul B, Tarhan $\mathrm{L}$. The effect of menadione-induced oxidative stress on the in vivo reactive oxygen species and antioxidant response system of Phanerochaete chrysosporium. Process Biochem. 2014;49(2):195-202. https://doi.org/10.1016/j.procbiol.2013.11.004.

64. Tanabe Y, Chino K, Ohnishi T, Ozawa H, Sagayama H, Maeda S, et al. Effects of oral curcumin ingested before or after eccentric exercise on markers of muscle damage and inflammation. Scand J Med Sci Sports. 2019;29(4):52434. https://doi.org/10.1111/sms.13373.

65. Panza VS, Wazlawik E, Schütz RG, Comin L, Hecht KC, Silva EL. Consumption of green tea favorably affects oxidative stress markers in weight-trained men. Nutr. 2008;24(5):433-42. https://doi.org/10.1016/..nut.2008.01.009.

66. Resnick AZ, Packer K. Oxidative damage to proteins: spectrophotometric method for carbonyl assay. Methods Enzymol. 1994;233:357-63. https://doi. org/10.1016/s0076-6879(94)33041-7.

67. Rodriguez MC, Rosenfeld J, Tarnopolsky MA. Plasma malondialdehyde increases transiently after ischemic forearm exercise. Med Sci Sports Exerc. 2003;35(11):1859-65. https://doi.org/10.1249/01.MSS.0000093609.75937.70.

68. Viitala PE, Newhouse IJ, LaVoie N, Gottardo C. The effects of antioxidant vitamin supplementation on resistance exercise induced peroxidation in trained and untrained participants. Lipids Health Dis. 2004;3(14):14-22. https://doi.org/10.1186/1476-511X-3-14.

69. Watson TA, Callister R, Taylor RD, Sibbritt DW, MacDonald-Wicks LK, Garg ML. Antioxidant restriction and oxidative stress in short-duration exhaustive exercise. Med Sci Sports Exerc. 2005;37(2):63-71. https://doi.org/10.1249/01. mss.0000150016.46508.a1.

70. Teixeira J, Deus CM, Borges F, Oliveira PJ. Mitochondria: targeting mitochondrial reactive oxygen species with mitochondriotropic polyphenolic-based antioxidants. Int J Biochem Cell Biol. 2018;97:98-103. https://doi.org/10.1016/j.biocel.2018.02.007.

71. Reis JS, Veloso CA, Mattos RT, Purish S, Nogueira-Machado JA. Estresse oxidativo: revisão da sinalização metabólica no diabetes tipo 1. Arch Endoc Metab. 2008;52(7):1096-105. https://doi.org/10.1590/5000427302008000700005 .

72. Sies H. Oxidative stress: a concept in redox biology and medicine. Redox Biol. 2015:4:180-3. https://doi.org/10.1016/j.redox.2015.01.002

73. Lytrivi M, Igoillo-Esteve $M$, Cnop M. Inflammatory stress in islet $\beta$-cells: therapeutic implications for type 2 diabetes? Curr Opin Pharmacol. 2018;43: 40-5. https://doi.org/10.1016/j.coph.2018.08.002.

74. Abdollahi M, Tabatabaei-Malazy O, Larijani B. A systematic review of in vitro studies conducted on effect of herbal products on secretion of insulin from Langerhans islets. J Pharm Sci. 2012;15(3):447-66. https:// doi.org/10.18433/J32W29.

75. Yosten GLC, et al. Peptides. 2018;100:54-60. https://doi.org/10.1016/j. peptides.2017.12.001

76. Kumar S, Sharma S, Vasudeva N. Review on antioxidants and evaluation procedures. Chin J Integr Med. 2017:1-12. https://doi.org/10.1007/s11655017-2414-z.

77. Santos JL, Araújo SS, Silva AMO, Lima CA, Vieira Souza LM, Costa RA, Aidar FJA, Voltarelli FA, Estevam CDS, Marçal AC. Ethanolic extract and ethyl acetate fraction of Coutoubea spicata attenuate hyperglycemia, oxidative stress and muscle damage in alloxan-induced diabetic rats subjected to resistance exercise training program. Appl Physiol Nutr Metab. 2020;45(4): 401-10. https://doi.org/10.1139/apnm-2019-0331.

78. Halliwell B, Whiteman M. Measuring reactive species and oxidative damage in vivo and in cell culture: how should you do it and what do the results mean? Br J Pharmacol. 2004;142(2):231-55. https://doi.org/10. 1038/sj.bjp.0705776.

79. Cobley JN, Close GL, Bailey DM, Davison GW. Exercise redox biochemistry: Conceptual, methodological and technical recommendations. Redox Biol. 2017;12:540-8. https://doi.org/10.1016/j.redox.2017.03.022.

80. Papadopoulou SK, Xyla EE, Methenitis S, Feidantsis KG, Kotsis Y, Pagkalos IG, Hassapidou MN, et al. Scand J Med Sci Sports. 2018;28(3):881-92. https://doi. org/10.1111/sms.13006.

81. Lamb KE, Thornton LE, King TL, et al. Methods for accounting for neighbourhood self-selection in physical activity and dietary behaviour research: a systematic review. Int J Behav Nutr Phys Act. 2020;17:45. https:// doi.org/10.1186/s12966-020-00947-2.

\section{Publisher's Note}

Springer Nature remains neutral with regard to jurisdictional claims in published maps and institutional affiliations.

\section{Ready to submit your research? Choose BMC and benefit from:}

- fast, convenient online submission

- thorough peer review by experienced researchers in your field

- rapid publication on acceptance

- support for research data, including large and complex data types

- gold Open Access which fosters wider collaboration and increased citations

- maximum visibility for your research: over $100 \mathrm{M}$ website views per year

At BMC, research is always in progress.

Learn more biomedcentral.com/submissions 